\title{
Decline of the Agricultural Welfare State?: An Assessment of Structural Reforms in Japan and Korea's Agricultural Sectors
}

\author{
JENNIFER S. OH*
}

This paper attempts to explain the diverging patterns of structural reform in Japan and Korea's agricultural sectors from 1985 to 2009. Why has structural reform proceeded more extensively in Japan than in Korea? The nature of Japan and Korea's agricultural policy communities, specifically the extent to which farm interests are meaningfully represented in the agricultural policy community, is an important factor shaping the structural reform experiences of Japan and Korea's agricultural sectors. In Japan, the inclusion of farm interests in the agricultural policy community strengthens government capacity to implement difficult reforms. In contrast, the exclusion of Korean farmers from its agricultural policy community weakens the Korean government's ability to restructure the agricultural sector against the wishes of farmers.

Keyteords: Japan, Korca, Agricultural Politics, Structural Reform, Farm Interests

- This work was supported by the Ewha Womans University Research Grant of 2009.

Full-time lecturer, Graduate School of International Studies, Ewha Womans University;

E-mail: Jenn.oh@ewha.ac.kr 


\section{INTRODUCTION}

$\mathrm{T}$ he conclusion of the Uruguay Round Agreement on Agriculture (URAA) in 1994 signaled a shift towards a tougher international environment on domestic policies that distort the production and price of agricultural goods. 1 Countries that have traditionally supported and protected their agricultural sectors now face increasing international pressure to open their agricultural markets and retrench existing support policies. In Japan and Korea, this change in theinternational environment presents a challenging policy task. Small-scale family farms in Japan and Korea are in no condition to withstand foreign competition without extensive government support. Both governments recognize that substantial structural reforms are necessary to strengthen the competitiveness of their farms prior to instituting market-oriented changes. The Japanese and Korean governments' attempts at agricultural structural reform have led to diverging outcomes. Structural reforms in Japan have produced visible results, whereas reforms in Korea have failed to alter the farm structure.

This paper attempts to explain the diverging patterns of structural reform in Japan and Korea's agricultural sectors from 1985 to 2009. Why has structural reform proceeded more extensively in Japan than in Korea? The nature of Japan and Korea's agricultural policy community-consisting of the core actors involved in the formulation and implementation of agricultural policies-is an important factor explaining this divergence. In Japan and Korea, the extent to which farm interests are represented in the agricultural policy community varies. In Japan, agricultural cooperatives and rural politicians are effective conduits through which farmers make their demands on the government and affect policy outcomes. Meaningful deliberation and negotiation occurs among the state, farm groups, and rural politicians. In Korea, the linkage and communication between farmers and the state are tenuous, leading to state domination of the agricultural policy community. As a result, political mobilization of farmers has occurred outside the existing agricultural policy community. Interestingly, the inclusion of Japan's powerful farm interests in its agricultural policy community actually aid in the implementation of market-oriented structural reforms under certain conditions, whereas the exclusion of farm groups within Korea's agricultural policy community has weakened the Korean government's capacity to implement substantial structural reforms.

The comparison between Japanese and Korean agricultural sectors is interesting for several reasons. First, Japan and Korea represent difficult cases for agricultural structural reform. Japan and Korea's small-scaled family farms derive a substantial portion of their revenue from government support policies. Between 1986 and 2009, the Organization of Economic Cooperation and Development's average percentage producer support estimate (PPSE) for Japan and Korea were respectively 56.5 percent and 63.7 percent. ${ }^{2}$ Moreover, Japan and Korea's rural population 
is aging rapidly, where the majority of the farm household population consists of individuals over 50 years old. ${ }^{3}$ Structural adjustment implies transforming these small and inefficient farms that are run by an aged population into larger commercialized farms that do not require heavy government support and protection. In other words, a considerable number of Korean and Japanese farmers risk losing their main source of livelihood with the consolidation of farmland and reduction in government support. Given these adverse conditions, Japan's successful structural reform relative to Korea is quite puzzling and requires explanation.

Second, the comparison highlights important differences underlying the politics of agricultural reform in Japan and Korea. As these cases demonstrate, one cannot assume that similar institutional and structural features in the agricultural sectors carry over to similar reform experiences. Existing policymaking institutions and actors critically shape reform outcome. This observation is particularly important for policy makers in advanced industrialized countries who need to reform their heavily protected and subsidized agricultural sectors. Third, structural reforms in Japan and Korea's agricultural sectors have broader economic ramifications. Successful structural reforms facilitate agricultural liberalization by reducing farm opposition to market opening. Agricultural liberalization, in turn, enables Japan and Korea to establish closer economic relations (e.g., free trade agreements) with major food exporting countries. Domestically, structural reforms can also decrease food prices as cost of food production declines with the emergence of more efficient farms.

Overall, the main objective of this paper is to gain a deeper understanding of the conditions that facilitate or impede structural reform in the agricultural sectors of advanced industrialized countries. The remaining sections are organized as follows. Section II situates the paper within the broader literature of agricultural politics. Section III assesses structural reforms in Japan and Korea's agricultural sectors. Section IV compares critical differences in Japan and Korea's agricultural policy communities and their impact on structural reform in Japan and Korea's agricultural sectors. Section five concludes.

\section{AGRICULTURAL POLITICS IN ADVANCED INDUSTRIAL COUNTRIES}

Advanced industrial countriestend to provide higher levels of government support and protection to their agricultural sectors than developing countries. Cross-national studies by Anderson, Hayami, and Honma (1986) and Lindert (1991) demonstrate that with economic growth and rising per capita income, countries shift from taxing to protecting their agricultural sectors. In particular, protection levels have increased more rapidly in East Asia than in other parts of the industrial world due to the rapid decline in the comparative advantage of their agricultural 
sectors. Korea and Japan are cases where postwar economic boom led to a rapid rise in agricultural protection and subsidies (Anderson, Hayami, and Honma 1986, 27).

Political factors largely explain high levels of agricultural protection and support in advanced industrial countries. As the agricultural sector shrinks, the cost of agricultural support and protection is diffused across a larger number of consumers who are insensitive to rising food prices. Consumers face a frec-rider problem, whereas the economicallymarginalizedfarmers have a greater incentive to mobilize and lobby for higher levels of subsidies and protection (Anderson 1986; Lindert 1991). Given the public's relative insensitivity to farm welfare programs, governments are more likely to respond to farm interests.

Farmers in advanced industrial countriesalso benefit frompolitical overrepresentationdue to favorable electoral rules and cohesion of the farm vote (Keeler 1996; Mulgan 1997). For example, prior to 1994. Japan's multi-member electoral district and single-non-transferable electoral system created incentives for the ruling Liberal Democratic Party (LDP) to seck out farm votes (Mulgan 1997; Ramseyer and Rosenbluth 1993). 4 Others point to corporatist government-farm group relations to explain high levels of agricultural support and protection (Keeler 1987; Sheingate 2001). Sheingate (2001) argues that the French and Japanese governments' close relations with their respective agriculture cooperatives resulted in the latter's active participation in theformulation and implementation of agricultural policies. The inclusion of farm interests in agricultural policymaking makes retrenchments of existing agricultural policies politically difficult.

Although not comprehensive, these factors represent important conditions that enable farmers in advanced industrial countries to wield a dominant influence over agricultural policies and reform. Since structural reform implies a revamping of existing agricultural policies, one should expect strong resistance from vested farm interests and political parties that fear the loss of farm votes. However, as the Japanese case demonstrates, conditions that maintained the status quo can also work in favor of structural reform. Japan represents a case where the close linkage between powerful farm groups and the government actually aid in the implementation of structural reforms. When Japanese farmers realized that some form of agricultural market opening was inevitable, they worked with the government to shape the process of structural reform. To a large extent, structural reform is possible due to the cooperation of powerful farm interests. On the other hand, structural reforms have been largely unsuccessful in Korea despite the relative political weakness of Korean farm interests compared to their counterparts in Japan.

This paper complements existing studies on agricultural politics in two ways. First, by comparing two difficult cases of agricultural structural reform, the paper challenges existing arguments that emphasize policy resiliency in the agricultural sector. In fact, a central argument rising from the paper is that conditions 
that have generally been viewed as unfavorable for reform-such as powerful farm groups and corporatist government-farm group relations-aid in the process of reform. Second, the paper analyzes critical differences in Japan and Korea's agricultural politics. Given strong similarities in their agricultural systems and policies, not much work has been done to identify the ways in which these two countries differ from one another. Overall, the paper hopes to offer insights to Japanese and Korean policy makers who face the monumental task of restructuring their agricultural sectors.

\section{STRUCTURAL ADJUSTMENT POLICIES AND TRENDS: 1985- 2009}

Structural adjustment policies in Japan and Korea involve creating larger farms, increasing the proportion of full-time farm households, and generating larger agricultural income. Both governments have also encouraged crop diversification to shift production away from heavily subsidized rice. In all these aspects, structural reform has proceeded more extensively in Japan than in Korea. The following section overviews key structural adjustment policies in Japan and Korea and then proceeds with an evaluation of structural changes in Japanese and Korean agricultural sectors.

\section{Japan}

(1) Key Structural Adjustment policies

For the first half of the postwar period, restrictive land laws prevented farmland consolidation and upheld the structure of small-scaled family farming in Japan's rural community. As negotiations over the URAA advanced in the early 1990s, however, the Japanese government realized that substantial adjustments were inevitable to comply with stricter international regulations on domestic support policies. Foremost, the Japanese government gradually relaxed existing land laws to encourage the emergence of larger farms. In 1993, the government introduced the Agricultural Management Framework Reinforcement Law to facilitate farmland transfer through leases, encourage rationalization of farm management through preferential tax and loan treatments, and introduce greater flexibility in farmland ownership and usage (Food and Agriculture Policy Research Center 1998, 63-74). The Structural Reform Special Zone Law in 2002 promoted business entry into agriculture by allowing business to raise farm products in special economic zones (Mulgan 2006, 157-158). By 2005, businesses were allowed to engage in farming outside the special zones (Ikematsu 2005). In 2009, amendments to the Agricultural Land Act opened up farming to a variety of companies and NPOs (Ministry 
of Agriculture, Forestry and Fisheries (MAFF 2009, 44).

The Japanese government also abolished existing commodity income stabilization programs that served as the backbone of Japan's agricultural price support system. 5 Instead, the government introduced a direct income transfer scheme for large farmers. The Core Farmers' Business Stabilization Bill, which came into effect in April 2007, limit direct payments to farmers with farmland of 4 hectares or larger (10 hectares in Hokkaido). Smaller farmers also have the option of joining a collective hamlet of at least 20 hectares with other villagers to be eligible for the support (Japan's Agrinfo Newsletter 2006). Considering that the average farm size in Japan is only 1.8 hectares (MAFF 2009, 43), the farmland size requirement is a huge incentive for farmers to consolidate their farmland. Overall, these policies reflect a growing emphasis within the Japanese government to create economically viable farms and to encourage non-traditional producers such as business from entering farming.

\section{(2) Structural Changes}

Japan's structural reforms have produced visible results. Figures on commercial farms ${ }^{\circ}$ indicate that although the number of farm houscholds decreased by 36 percent between 1995 and 2009 , the percentage of full-time farm households increased from 16.1 to 23.7 percent (Table 1). Moreover, the proportion of income derived from farming increased in the same time period from 16.1 to 22.8 percent. "What these results illustrate is that despite the continued dominance of part-time farm households that depend largely on non-agricultural income sources, there has been a modest and consistent shift towards full-time farm households that rely on farming for income.

In terms of farm size, there has been a gradual shift to larger farm households. Between 1995 and 2009, the percentage of farm households with less than 1hectare of farmland decreased by approximately 4 percent, while relatively larger farm households with more than 2 hectares of farmland increased by approximately 4 percent. These results, however, should not be overstated since in 2009 over 80 percent of farm households continued to have less than 2 hectares of farmland, which is extremely small from aninternational perspective. However, in response to relaxed land laws, an increasing number of corporations other than agricultural production legal persons (e.g., food-related companies) are entering into farming. Also, the number of community-based cooperatives and agricultural legal persons has been on the rise, signifying that the government's effort to encourage the emergence of larger non-family farms is generating positive results (MAFF 2009, 41-2).

In the area of crop diversification, the government achieved greater success in shifting production away from rice (Table 2). The proportion of rice out of the total agricultural production value decreased from 32.9 percent in 1985 
to 22.3 percent in 2009. Instead, vegetables took up an increasingly larger share of the total agricultural production value, rising from 18.1 percent to 25.2 percent in the same time period. The decline in rice production potentially suggests a decline in the number of smaller rice paddies that have dominated Japan's rural landscape. Overall, Japan has achieved modest levels of success in increasing the share of full-time farms and agricultural income, shifting towards larger farms, and diversifying crop production.

Table 1. Farm Households by Degree of Engagement and Size, Japan (1000 HOUSEHOLDS)

\begin{tabular}{cccccc}
\hline & Total & Full-time & $0-1.0$ ha & $1.0-2.0$ ha & 2.0 +ha \\
\hline 1985 & 4376 & 626 & 3038 & 883 & 346 \\
1990 & 3834 & 592 & 2609 & 782 & 348 \\
1995 & 2652 & 428 & 1558 & 682 & 339 \\
2000 & 2337 & 426 & 1358 & 592 & 324 \\
2005 & 1963 & 443 & 1109 & 498 & 304 \\
2009 & 1699 & 403 & 933 & 432 & 289 \\
\hline
\end{tabular}

SOURCE: Japan Statistical Yearbook, Farm Households by Degree of Engagement and Size of Operating Cultivated Land (1925-2009), accessed August 10, 2011, hetp://www.stat.go.jp/english/data/

NOTE: 1) Figures before and after 1995 are not comparable since the latter only refers to commercial farms. MAFF classifies farms with at least 0.3 hectare of farmland or annual sale of 500,000 yen and over as commercial farms. 2) Figures on farm household size exclude farms in Hokkaido.

Table. 2. Agricultural Production by Major Commodities, Japan (\% Out of Total. Value)

\begin{tabular}{lcccccc}
\hline & Total & Rice & Vegetables & $\begin{array}{c}\text { Fruits and } \\
\text { Nuts }\end{array}$ & $\begin{array}{c}\text { Livestock ind } \\
\text { its Products }\end{array}$ & Other \\
\hline 1985 & 100 & 32.9 & 18.1 & 8.1 & 28.0 & 12.7 \\
1990 & 100 & 27.8 & 22.5 & 9.1 & 27.2 & 13.3 \\
1995 & 100 & 30.5 & 22.9 & 8.7 & 24.1 & 13.8 \\
2000 & 100 & 25.4 & 23.2 & 8.9 & 26.9 & 15.6 \\
2004 & 100 & 22.8 & 24.6 & 8.9 & 27.9 & 15.8 \\
2009 & 100 & 22.3 & 25.2 & 8.4 & n/a & n/a \\
\hline
\end{tabular}

SOURCE: MAFF, 2005, Statistics of Agriculture, Forestry and Fisheries, "Heisei 16 nen Nogyo So Sanshutsu" (2004 Total Agricultural Yield); MAFF, Monthly Statistics of Agriculture, Forestry and Fisheries, Summary of Production, accessed August 10, 2011, http://www.maff.go,jp/e/tokei/kikaku/monthly_e/pdf/g000003.pdf.

\section{Korea}

\section{(1) Key Structural Adjustment Policies}

Similar to Japan, restrictive land laws prevented the creation of large farms 
in Korea. The Land Reform Act of 1949 had placed a 3 hectare ceiling on farm ownership, effectively solidifying the small-scale family farm structure of Korean rural communities. Starting in the late 1980 s, the Korean government revised land laws and introduced farm programs to consolidate farmland and encourage business entry into farming. In 1993, revisions in the Land Reform Act of 1949 allowed farmers to own up to 20 hectares of land. The following year, the Farmiand Act of 1994-which repiaced the Land Reform Act of 1949 . further relaxed land restrictions by removing the ownership ceiling in agricultural promotion areas and allowing certain corporations and cooperatives to engage in farming ( $\operatorname{Lim} 2003,356-7$ ).

The Korean government also introduced the "Farm Size Optimization Program" in 1990 to create larger and more efficient farms. The program targeted small rice farmers who were given access to cheap loans to purchase, lease or exchange farmland for the purpose of farm consolidation ( $\mathrm{m}$ 1997, 283-284). ${ }^{8}$ The Korea Agricultural and Rural Infrastructure Corporation (KARICO), the government agency in charge of the program, invested 2.4 trillion won between 1988 and 2002 through the Farm Size Optimization Program (Kang 2005, 50).9

In the mid-1990s, the Korean government revamped existing government support programs to comply with the outcome of the URAA. Specifically, the Korean government revised its half a century old government rice purchase program that heavily distorted rice prices. After initially testing schemes on direct payments and income deficiency payments for rice, the government finally abolished its rice purchase program in 2005. Instead, the government shifted to a decoupled rice support program by introducing the Rice Income Deficiency Payment to secure farm income ( $\operatorname{Lim} 2007,171-7)$. The significance of the new rice program lies in its potential to shift production away from rice and thus increase crop diversification. Reduction in rice production also has strong potential to alter the rural landscape by reducing the number of small family-owned rice paddies.

\section{(2) Structural Reforms}

Changes in Korea's full-time farm households, agricultural income, and farm size point to extremely limited, if not failed, structural adjustments. Between 1985 and 2009, the proportion of full-time farm households decreased from 78.9 percent to 58 percent (Table 3). In addition, current farm households in Korea (both full-time and part-time) on average derive only 31 percent of their income from farming. The figure was nearly double that in 1985 at 64.5 percent. ${ }^{10}$ In other words, the share of agricultural income has been declining in Korean farm households, further pointing to the weak economic viability of Korean farms.

The Korean government's efforts to enlarge farm size failed to reduce the 
proportion of small farm households with less than 1 hectare of farmland. Instead, farms with less than 1 hectare of farmland actually increased by lpercent between 1985 and 2009 (Table 3). Currently, over 64 percent of Korean farm households have less than 1 hectare of land and over 91 percent of farm households have less than 3 hectares of land. While some scholars such as Lim (2003) and Kang (2005) have argued that the Farm Size Optimization Program substantially increased the number of farm households bigger than 3 hectares, the gains are extremely modest when taking into account that these farms constitute only 7.5 percent of the total farm households in 2009 (Table 3). When looking solely at large farm households with over 10 hectares of farmland, the number increased from 0 in 1985 to 6200 in 2009 , which amounts to a mere 0.5 percent of total farm households in 2009.11

Table 3. Farm Households by Degree of Engagement and Size, Korea (1000 HoUSEHOL.DS)

\begin{tabular}{cccccc}
\hline & Total & Full-time & $0-1.0$ ha & $1.0-3.0$ ha & $3.0+$ ha \\
\hline 1985 & 1925 & 1518 & 1220 & 637 & 23 \\
1990 & 1767 & 1052 & 1027 & 673 & 44 \\
1995 & 1501 & 819 & 865 & 541 & 70 \\
2000 & 1383 & 902 & 819 & 465 & 85 \\
2005 & 1273 & 796 & 788 & 374 & 93 \\
2009 & 1195 & 693 & 770 & 321 & 90 \\
\hline
\end{tabular}

SOURCE: Korean Sratistical Information Service, Census Agriculture, accessed August 10, 2011 , http://www.kosis.kr/abroad/abroad_03List.jsp?parentid $=$ B000_10, B000.

Tabie 4. Agriclitural. Production by Major Commodities, Korfa (\% OUT OF TOTAL VAIUE)

\begin{tabular}{ccccccc}
\hline & Total & Rice & $\begin{array}{c}\text { Fruits and } \\
\text { Vegetables }\end{array}$ & Livestock & $\begin{array}{c}\text { Dairy Products } \\
\text { and Eggs }\end{array}$ & Other \\
\hline 1990 & 100.0 & 36.6 & 26.6 & 15.7 & 6.3 & 14.9 \\
1995 & 100.0 & 25.7 & 37.8 & 16.9 & 5.7 & 13.9 \\
2000 & 100.0 & 32.9 & 29.2 & 18.3 & 6.9 & 12.7 \\
2005 & 100.0 & 24.3 & 28.5 & 25.1 & 8.4 & 13.6 \\
2010 & 100.0 & 16.3 & 28.6 & 33.0 & 8.9 & 13.2 \\
\hline
\end{tabular}

SOURCE: Korean Statistical Information Service, Value of Production in Agriculture and Forestry (19892010), accessed August 10,2011, http://www.kosis.kr/abroad/abroad_03List.jsp?parentld = B000_10, B000.

Crop diversification, on the other hand, has met with more success than in other areas. As illustrated in Table 4, the contribution of rice production to the total value of agricultural production declined by more than 20 percent between 1990 and 2010. Among all grain productions, rice continues to dominate, accounting for 84.5 percent of the total value of grain productions in 2010.12 
In the same time period, the contribution of livestock to the total value of agricultural production increased by nearly 20 percent. The contribution of other major commodities such as fruits and vegetables, and dairy products and eggs remained fairly consistent in the past two decades.

Overall, structural adjustments failed to increase the share of full-time farmers and agricultural income. In regard to farm size, small farms with less than lhectare of farmland and relatively larger farms with more than 3 hectares of farmland both increased in number. This mixed result suggests that the government's effort at farmland consolidation was not entirely successful. The one area that underwent successful adjustment was crop diversification, which exhibited a drastic decline in rice production.

\section{Discussion}

Comparison of structural changes in Japan and Korea's agricultural sectors demonstrate that structural adjustment have proceeded more extensively in Japan than in Korea. One interesting observation is that unlike Korea where full-time farm households continue to remain the majority, Japanese farm households are predominantly part-time and rely less on agricultural income. Although Kim and Lee (2004) argue that structural adjustment is more burdensome and difficult in Korea due to Korean farmers' heavier reliance on agricultural income, one could as easily make the opposite observation. Part-time farmers might be less willing to accede to structural reform measures since they have less to gain from giving up their small plots of land for restructuring. Regardless of the economic welfare implications of structural adjustment, part-time farmers are as likely to oppose structural adjustment measures compared to full-time farmers. In fact, small-scaled part time farmers are the main opposition source to market-oriented reforms in Japan.

\section{AGRICULTURAL POLICY COMMUNITIES IN JAPAN AND KOREA}

Despite strong similarities in the history and institutions of agricultural policies, critical differences underlie Japan and Korea's agricultural policy communities. The Japanese agricultural policy community represents a classic case of the iron triangle among the bureaucracy, interest groups, and politicians. Agricultural policy changes stem from compromises and negotiations among these core actors. On the other hand, nural representation is largely absent within Korea's agricultural policy community. Political mobilization of Korean farmers has occurred outside theagricultural policy community in the form of radicalized farmers' movements, often times pitting the state against farmers. 
Whether or not farm interests are meaningfully represented in the agricultural policy community critically shapes the course and outcome of market-oriented reforms in the agricultural sector. Under normal circumstances, corporatist-farm group relations or the presence of an iron triangle hinder policy changes that go against farm interest. However, when reform is inevitable due to growing international pressure for market liberalization, close collaboration among state. political and farm actors work in favor of reform. Foremost, once centralized and cohesive farm groups agree to the reform, they mitigate opposition from their members and create a favorable public environment for reform. Second, by working within the system, farm groups are able to obtain favorable government compensation. Third, deliberation between the state and farm groups weakens resistance by creating the perception that the reform was agreed upon collectively. Lastly, the inclusion of farm interests aids in the effective implementation of structural adjustment policies. The organizational resources of agricultural cooperatives are essential in the effective implementation of structural adjustment policies.

The following section focuses specifically on the core characteristics of Japan and Korea's agricultural policy communities. A close examination of the relations among agricultural bureaucrats, politicians, and farm groups reveal that the political strength of farm groups and the way in which they are included in the policymaking process matters for reform.

\section{Japan}

Japan's agricultural policy community consists of the Japan Agricultural Cooperative Association (JA, formerly known as $N \bar{O} k y \bar{O}$ ), nōrinzoku (agriculture policy tribe) politicians, and MAFF. For much of the postwar period, these three groups of actors have dominated all aspects of Japanese agricultural policymaking at the exclusion of external interests (Mulgan 2005; Mulgan 2006; Sheingate 2001). All three actors have a strong interest in maintaining Japan's costly agricultural system and small-scaled family farm structure. Individual family farms are an important source of votes for nōrinzoku politicians and the core constituency for JA and MAFF (Bullock 2003, 182). However, Japan's agricultural policy community should not be viewed simply as an obstacle to reform. Close collaboration among JA, nōrinzoku politicians, and agricultural bureaucrats suggest that Japan's agricultural policy community has the political resources, the institutional capacity, and the grass root support to implement difficult policies.

At the grass roots, Japan's powerful farm group JA is an effective channel through which Japanese farmers gain access to the agricultural policy community. Representing 99 percent of Japanese farm households, JA is a powerful political organization that delivers farm votes. During election times, JA's political organization, the National Council of Farmer's Agricultural Policy Campaign Organization, engages in grass-roots campaigns, and provides funds and various forms 
of organizational support to candidates they support (Ikuo and Steel 2010, 34; Mulgan 1997, 883-7). Local branches of JA are also forums through which politicians come into contact with individual farmers togenerate political support.

The political leverage of JA lies in its ability to punish as well as reward political parties and individual politicians with its electoral strength. In fact, since the 1960s, JA has played a key role in securing farm votes for the LDP and thus contributing to the LDP's dominance. In return for farm votes, the LDP provided generous farm subsidies and favorable price support schemes for agricultural commodities. Opposition parties have adopted a similar strategy by advocating even higher levels of support than the LDP in hopes of gaining the farm vote (Bullock 2003, 179; Curtis 1988, 49-51). In short, JA's attractiveness as a political ally has provided Japanese farmers with a direct linkage to state actors and politicians.

At the political level, the nörinzoku, consisting of LDP politicians with an expertise in agricultural policies, actively seeks to further farm interests. Considered one of the most powerful zokus (policy tribe), nōrinzoku politicians dominate the agricultural policy agenda and maintain frequent and close ties with JA and MAFF officials to shape policy outcomes. The LDP nōrinzoku politicians have traditionally played a major role in shaping the LDP's and ultimately the government's decision on agricultural policies (Sheingate 2001, 194). In recent years, Mulgan $(2011,22-5)$ notes that norrinzoku politicians have lost their previous influence under the reign of the Democratic Party of Japan (DPJ). The DPJ seeks to undermine the LDP and JA's influence by currying to the interests of small farmers who have been hure by recent structural reforms. Yet, as long as intense competition between the DPJ and LDP over farm votes continues, nörinzoku politicians are a viable and effective channel through which farmers influence policies.

The close linkage among JA, nōrinzoku politicians, and farm voters ensure that farm interests are effectively represented within the agricultural policy community and the National Diet. Moreover, even state interest is closely aligned to farm interests in Japan. Unlike in Korea, MAFF exercises strong policy jurisdiction over agricultural issues, and operates as a powerful and autonomous actor from the political leadership (Mulgan 2005). Even in the realm of foreign economic policies, MAFF independently negotiates terms on agricultural products and even stalls trade negotiations against the wishes of the other ministries (Manger 2005). In short, Japan's agricultural policy community acts as a fairly cohesive unit to promote farm interests.

Structural adjustment policies in Japan reflect a compromise among MAFF, JA and nörinzoku politicians (Mulgan 2011). All three actors recognize that structural adjustments are inevitable given changing domestic and international conditions. As such, MAFF, JA, and nōrinzoku politicians use their organizational resources and networks to mobilize farm support for the proposed change and 
actively encourage reluctant farmers to consolidate their farmland. Such mobilization of farm support is not possible without a prior history of credibility and trust between farmers and their representatives. In this sense, structural reform is easier when powerful farm groups are included in the policymaking process. Yet, the agricultural policy community's support for structural reforms does not carry over to market liberalization. MAFF, JA, and nōrinzoku politicians are actively against agricultural libcralization as evidenced in the recent opposition to the Trans Pacific Partnership (Urata 2011). The position of Japan's agricultural policy community is to delay market opening while gradually strengthening the competiveness and economic viability of their farmers.

\section{Korea}

Unlike in Japan, Korea's agricultural policy community is heavily characterized by strong government presence and directive. Both the Ministry for Food, Agriculture, Forestry and Fisheries (MIFAFF) and the National Agricultural Cooperative Federation (NACF or NongHyup) reflect government policy strategies and interests rather than that of the farmers. The NACF was initially constructed as a parastatal agency, "as an implementation arm of other central government agencies, especially (MIFAFF)" (Burmeister 1999, 114). NACF's attempt to separate from the state and politically rehabilitate itself in the wake of democratization brought about strong government reprisals such as the prosecution of the federation's president. Ultimately, the newly democratized government depoliticized NACF by transforming its function to mainly banking and provision of economic services (124-127). In short, the NACF failed to establish itself as a powerful interest group for farmers, but instead has evolved into a quasi-public organization that attracts farmers' affiliation through cheap loans and marketing services.

Instead of the NACF, the National Federation of Farmers Movement (NFFM) has served as the most politically active farm organization since democratization. The NFFM is a strong opponent of market-oriented reforms that can potentially harm the livelihood of Korean farmers ( $K i m$ 2006, 144-5). Yet, the influence of the NFFM is highly limited. Generally viewed as a leftist and radical farm group, the NFFM can only influence agricultural policies from outside the agricultural policy community. As a result, the NFFM often resorts to violent street demonstrations and protests, which in turn has weakened broader public support and sympathy.

The other channel through which farmers potentially influence agricultural policies is rural politicians. However, given weak institutionalization of Korean political parties (Lee 2009), rural politicians are not cohesively organized as a policy pressure group. What this implies is that Korean farmers are not politically represented within the agricultural policy community. Instead, throughout the years, farmers have responded to unfavorable government policies through violent 
demonstrations in front of the National Assembly and the streets. For example, in 2004, farmers clashed violently with riot police while protesting against possible increases tominimum access rice (Kim 2004). More recently, protestingfarmers have taken part in the candlelight vigils protesting against the import of U.S. beef. In both cases, political parties did not play an active role in mediating between farmers and the state.

Due to the lack of farm representation, Korea's agricultural policy community does not reflect the broader consensus of the rural community. In fact, high levels of distrust characterize the relations between Korean farmers and the government. Due to poor implementation of structural adjustment policies and compensation schemes, government policies have lost credibility among farmers (Kim 2004, 19; Kim and Hwang 2009, 27). The perceived disconncet between structural adjustment policies and reality and the lack of support for government policies among the farmers stem from the lack of linkage between the state and farm interests. Farmers have no means to actively participate in agricultural policymaking, leading to strong resistance to government efforts at structural reform.

\section{CONCLUSION}

In the past two decades, structural adjustment has proceeded more extensively in Japan than in Korea. Japan's agricultural structural reform challenges the conventional notion that corporatist state-farm group relations hinder policy reform. In fact, structural adjustment in Japan has proceeded with the support of the core actors comprising its agricultural policy community-MAFF, JA, and nörinzoku politicians. Structural reform was made easier by the active engagement of farm interests. Structural reform efforts in Korea, however, have suffered from poor implementation and strong resistance due to the lack of farm interest representation within its agricultural policy community. High levels of distrust between Korean farmers and the state continue to generate violent confrontations between the two as farmers resort to non-institutionalized means to make their demands on the government. In order to meet the needs of Korea's faltering farm sector, there is a need to create stronger linkage between farmers and the state.

\section{REFERENCES}

Anderson, K. 1986. Economic Growth, Structural Change and the Political Economyof Protection. In The Political Economy of Agricultural Protection: East Asia in International Perspective, eds. Kym Anderson and Yujiro Hayami. 
Sydney: Allen and Unwin.

Anderson, K., Y. Hayami, and M. Honma. 1986. The Growth of Agricultural Protection. In The Political Economy of Agricultural Protection: East Asia in International Perspective, eds. Kym Anderson and Yujiro Hayami. Sydney: Allen and Unwin.

Bullock, R. 2003. Redefining the Conservative Coalition: Agriculture and Small Busincss in 1990s Japan. In The State of Civil Society in Japan, eds. Frank Schwartz and Susan Pharr. Cambridge: Cambridge University Press.

Burmeister, L. L. 1999. From Parastatal Control to Corporatist Intermediation. In Corporatism and Korean Capitalism, ed. Dennis L. McNamara. NewYork: Routledge.

Curits, G. 1988. The Japanese Way of Politics. New York: Columbia University Press.

Food and Agriculture Policy Research Center. 1998. Changes in Japan's Agrarian Structure. Tokyo: Food and Agriculture Policy Research Center.

lkematsu, H. 2005. Can Farming go Corporate? Move to Set Up Company-Run Farms Seen as a Future of Agriculture. Daily Yomiuri. March 16.

Im, S.-B. 1997. Policy Directions of Farm Size Optimization Program in Korea. Journal of Rural Detelopment 20(Winter): 281-298.

Japan Agrinfo Newsletter. 2006. The Core Farmers' Business Stabilization Bill Enacted. 23(10): Accessed September 9, 2011. http://www.jaicaf.or.jp/agrinfo/0607/Report_231004.htm.

Kabashima, 1. and G. Steel. 2010. Changing Politics in Japan. Ithaca: Cornell University Press.

Kang, H.-J. 2005. Changes in Farm Size Distribution in Korea: Evidence From Farm-Level Panel Data 1998-2002. Journal of Rural Development 28(Summer): 49-63.

Keeler, J. T. S. 1996. Agricultural Power in the European Community: Explaining the Fate of CAP and GATT Negotiations. Comparative Politics 28(2): 127-149.

Kim, C.-K. 2006. The Rise and Decline of Statist Agriculture and the Farmers Movement in South Korea. Korea Observer 37(1): 129-147.

Kim, H. and Y.-K. Lee, 2004. Agricultural Policy Reform and Structural Adjustment in Korea and Japan: In Search of Grace Period for Korea. Korean Journal of Agricultural Economics 45(3): 1-26.

Kim, H.S. and S.-W. Hwang. 2009. 한국농업 정책의 시차적 접근: 농가소득 지원 정책과 농업구조 조정정책을 중심으로 [Perspective on Korean Agricultural Policies: Examination of Farm household income support and Agricultural Structural Adjustment Policies]. Hankuk Hangjung Nonjip 21(1): 169-2001.

Kim, K. 2004. South Korea Farmers Protest Over Rice. BBC News. November 19. Accessed October 31, 2011.hetp://news.bbc.co.uk/2/hi/asia-pacific/40249 49.stm. 
Kim, Y.-T. 2004. Changes in Agricultural Public Finance Policies in Korea Since Uruguay Round. Journal of Rural Development 27(Summer): 17-31.

Lee, Y. 2009. Democracy without Parties? Political Parties and Social Movements for Democratic Representation in Korea. Korea Observer 40(1): 27-52.

Lim, S.-S. 2007. Transition to Decoupled Rice Support and its Production Effects in Korea. Journal of Rural Development 31(2): 169-185.

Lim, S. H. 2003. Liberalization of South Korean Agriculture and Statc Policies. Korea Observer 34(2): 345-368.

Lindert, P. 1991. Historical Patterns of Agricultural Policy. In Agriculture and the State: Growth, Employment, and Poverty in Developing Countries, ed. C. Peter Timmer. Ithaca, NY: Cornell University Press.

MAFF. 2009. Annual Report on Food, Agriculture and Rural Areas in Japan. Accessed September 9, 2011. http://www.maff.go.jp/e/annual_report/2009/ind ex.heml.

Manger, M. 2005. Competition and Bilateralism in Trade Policy: the Case of Japan's Free Trade Agreements. Review of International Political Economy 12(5): 804-888.

Mulgan, A. G. 1997. Electoral Determinants of Agrarian Power: Measuring Rural Decline in Japan. Political Studies XLV: 875-899.

Mulgan, A. G. 2005. Japan's Interventionist State: the Role of the MAFF. New York: Routledge.

Mulgan, A. G. 2006. Japan's Agricultural Policy Regime. New York: Routledge. Mulgan, Aurelia G. 2011. Agricultural Politics and the Democratic Party of Japan. ANU Japanese Studies Online 1ssue 2. Online at: http://japaninstitute.anu.edu.au/japanese_studies/.

Ramseyer, M. and F. Rosenbluth. 1993. Japan's Political Market Place. Cambridge: Cambridge University Press.

Sheingate, A. 2001.The Rise of the Agricultural Welfare State: Institutions and Interest Group Power in the United States, France, and Japan.Princeton: Princeton University.

Urata, S. 2011. Deflated Hopes for Japan Joining the TPP Negotiations. East Asia Forum. January 18. Accessed September 1, 2011. http://www.eastasiaforum. org/2011/01/18/deflated-hopes-for-japan-joining-the-tpp-negotiations/. 


\section{ENDNOTES}

' See Timothy Josling. Agricultural Trade Policy: Completing the Reform (Washingtun, D.C: Institute for International Economics 1998).

PPSE measures the percent of farm receipts derived from government policies in the form of transfers from consumers and taxpayers. A PPSE of 57.8 percent indicates that 57.8 percent of farm receipts wefe derived from government support policies. Data from OECD, Producer and Consumer Support Estimates Database, accessed Octotet 31, 2011, hetp://www.occd.org/document/59/0,3746,en_2649_ $3740 ! 39551355$ ! ! ! 3710!,60.htm!. For mure discussion on producer support estimate, see OECD, Introduction to OECD Producer Support Estimate and Related Indicators of Agricultural Support, accessed October 31, 2011, hetp://www.oecd.org/dataoecd/57/5/43411396.pdt.

In 2009, 57.7 percent and 63.2 percent of the farm household population were over 50 years old respectively in Japan and Kurea. Korean Statistical Information Service, Census Agriculture, accessed August 10, 2011. hetp://www.kosis.kr/abroad/abroad_03List.jsp?parentld = B000_10, B000; 85th Statistical Yearbook of MAFF. Number of Household Member by Age Group, accessed August 10, 2011, http://www maff.go.jp/e/tokei/kikaku/nenji_e/85nenji/index.html\# nse002.

- The electoral reform of 1994 created a mixed electoral system of 300 single member district seats and 180 proportional representation (PR) seats in the lower house of the Diet. Due to the practice of dual-listing-that is placing candidates who ate unsuccessful in the single member district on the PR party list-politicians continue to maintain ties with theit old constituents. As a result, the reform did not significantly alter farm politics. See Ikuo Kabashima and Gill Steel, Changing Politics in Japan (Ithaca: Cornell University Press, 2010), 43-44.

The major income stabilization funds are the Rice Farming Income Stabilization Fund, Soybean Farming Income Stahilization Fund, Milk Direct Payment, and Wheat and Barley Income Stabilization Fund.

In 2005, commercial farms accounted for (6) percent of farm houscholds. See MAFF, 85th Statistical Yearbook of MAFF (2009)-2010). Number of Farm Houschold and Farm Houschold Population. accessed August 10, 2011. hetp://www.maff.go.jp/e/tokei/kikaku/nenji_e/85nenji/index.heml\#nse001. Figures from 1995 to 2005 from Japan Statistical Yearbook, Receipts and Disbursements of Farm Houscholds (1985-2007), accessed August 10, 2011, hrtp://www.stat.go.jp/english/data/nenkan/1431(07. hem. Figure for 2009 from MAFF, 85th Statistical Yearbook of MAFF (2009-2010), Farm Management and Economy by Agricultural Region, acessed August 10, 2011, hetp://www maff.go.jp/e/tokei/ki$\mathrm{kaku} / \mathrm{nenji}$ e/85nenji/index.hemi \# nse002.

- Government loans were given out at an annual interest rate of 4 percent (repayment in 20 years, 2 year grace period).

From 1988.1989, government assistance to farmers were implemented through agricultural cooperatives. However, government assistance did not cover loans for leasing at this time.

(1) Kurean Statistical Information Service. Farm Economy, accessed August 10, 2011, hrtp://www.kosis. $\mathrm{kr} / \mathrm{abroad} / \mathrm{abroad}$ 03List.jsp? parentld $=$ B000_10, B000.

11 Korean Statistical Information Service, Census Agriculture, accessed August 10, 2011, hetp://www.kosis. kr/abroad/abtoad_03List.jsp?parentld = B000_10, B000.

12 Kotean Statistical Information Service, Value of Production in Agriculture and Forestry (1989-2010), accessed August 10,2011, http://www.kosis.kr/abroad/abroad_031.ist.jsp?parentld = B000_10, B000. 